\title{
FEATURES OF THE FUNCTIONING OF NATIONAL PENSION SYSTEMS OF EASTERN EUROPE AND UKRAINE IN THE MODERN CONDITIONS
}

\author{
Agnieszka Parlinska ${ }^{1}$, PhD; Volodymyr Rudyk ${ }^{2}$, PhD \\ ${ }^{1}$ Warsaw University of Life Sciences (WULS - SGGW); ${ }^{2}$ Podilsky State Agrarian Technical University
}

\begin{abstract}
Due to the global trends, an increasing proportion of older people, a decline in fertility and hence a reduction in the population, European countries are forced to pursue pension reforms aimed at achieving social and economic goals. The countries of Eastern Europe as well as Ukraine began reforming their national pension systems in the 1990s of the twentieth century. In accordance with the current pension legislation in all these countries, multi-tier pension systems are envisaged.

The objective of this paper is to introduce the peculiarities of functioning of the national pension systems of Eastern European and Ukrainian countries in the context of global challenges in the demographic and social spheres. The analysis of the literature and comparative analysis of the main parametric indicators in pension system reformation were the research methods used in the paper. Special attention has been paid to determine the priorities for further development of national pension systems.
\end{abstract}

Key words: demographic problems, national pension system, social insurance.

JEL code: J1, H55.

\section{Introduction}

Global trends, which are manifested today in the demographic sphere, are characterized by processes of aging of the population. For most European countries, the demographic situation, in addition to increasing the proportion of older people, is characterized by a decline in fertility, and hence a reduction in the population.

In 2017, nearly one fifth (19\%) of the EU population was 65 years of age or older. The proportion of people aged 80 and over should increase more than double by 2080 to reach $13 \%$ of the population (Population Structure and ...., 2018). As a result, the proportion of people of working age decreases, and the relative number of those who retired is expanding. This leads to an increase in the financial burden on the able-bodied population, which must provide the social expenditures necessary for citizens of retirement age to meet their vital needs. This causes also negatively affect the economic mechanisms of the functioning of pension systems of states. In order to solve the problems of pensions, European countries are forced to pursue pension reforms aimed at achieving social and economic goals that are universally recognized in a civilized society: creating objective economic conditions to guarantee decent living standards for every person in an incapacitated period.

For a reform of the Ukrainian national pension system, comparative analysis of pension models of Eastern European countries is especially relevant. They have also faced a demographic crisis and are taking steps to reform their national pension systems. Eurointegration processes in Ukraine require orientation of pension model to achieve a high level of social standards in the pension sector, which are trying to form the countries of Eastern Europe. At the same time, it should be noted that when comparing with the experience of Eastern European countries, it is necessary to take into account a set of practical features of their national pension systems.

The aim of the research is to review the peculiarities of functioning of national pension systems of Eastern Europe and Ukraine in the context of global challenges in the demographic and social sphere. The comparative analysis of the main parametric indicators in national pension systems changes was provided. The rating of quality of life and well-being of the elderly people was calculated e.t.: material security, health status, employment and education favourable environment. The

\footnotetext{
${ }^{1}$ Agnieszka Parlinska, PhD; ORCID: https://orcid.org/0000-0001-6640-3097; Tel.: + 4822593 4194; e-mail: agnieszka_parlinska@sggw.pl

2 Volodymyr Rudyk, PhD; ORCID: https://orcid.org/0000-0001-9011-4543; mail: rudyk_vk@meta.ua;
} 
priorities for further development of national pension systems was determined as well. Data and information were taken from the literature, the statistics of the World Bank and the OECD.

\section{Literature overview}

Under the current conditions, major international institutions, such as the United Nations, the International Labour Organization (ILO), the OECD, the World Bank, take major part in the formation and reform of national pension systems of European countries, including Eastern Europe and Ukraine. At their initiative, the main strategies, concepts, programs of the development of national pension systems are developed, taking into account the global risks facing society. The IMF, together with the World Bank and other international financial institutions, provides financial assistance for pension reforms to Eastern Europe and Ukraine. The legal framework developed by the above-mentioned international organizations is a guideline and the main reason for implementing practical steps in the reform of the pensions sector. (Convention of the Organization ..., 1960; World Bank Statistics ..., 2018; Convention of the International ..., 1952)

The International Labour Organization for a long time plays a key role in international regulation of processes development of pension and social security systems. Therefore, in 1952 the ILO Convention approved minimum social security standards (Convention of the International ..., 1952), which must be respected by countries in the construction of their pension systems. It is this international document that defines social insurance as one of the main sources of the social protection system and the pension system. In this connection, the calculation of pension payments with the size of the previous earnings, the length of the insurance period and the amount of insurance premiums paid is logically related. It should be noted that Ukraine, on 6 June 2017, ratified this ILO Convention, having undertaken to fulfil its requirements.

In 2002, the Second World Assembly on Aging, sponsored by the United Nations, approved the Madrid International Plan of Action on Aging. The ultimate goal of its implementation is the transition from "aging society" to "a society of equal opportunities for people of all ages" (Annex II. Of the Madrid International, ...2002).

Nowadays, one of the main documents defining the institutional approach to speeding up the process of social reforms in the EU is the strategic document "European Social Rights Support" adopted in April 2017 by the European Commission (Establishing a European Pillar ..., 2017). One of the key goals of this document is to bring the parameters of social protection of the EU member states closer together. This also applies to Eastern European countries. Today, this gap between them and the developed Western European countries is quite large and this problem needs to be addressed.

\section{Research results and discussion}

The countries of Eastern Europe, as well as Ukraine, began reforming their national pension systems in the 1990s of the twentieth century. In accordance with the current pension legislation in all these countries, multi-tier pension systems are envisaged. It should be noted that Eastern European countries have been using the three-tiered pension model that they introduced in the early 2000s for a long time. Practical use in Ukraine is still only the first and third pillars of the national pension system. The full introduction of the second level has been constantly carried over and now the government is planning only in 2021 (European Experience of ..., 2017).

The reason for the reform of the national pension systems of the countries of Eastern Europe since the mid-1990s was that the joint pension systems of these countries were already unable to 
provide a sufficient level of pension provision for citizens. Poland became one of the first pension reform in Eastern Europe in 1998. Its successful implementation helped the country to cope with the global economic crisis painlessly. The peculiarity of the Polish pension system is that people born before 1949 receive a pension under the so-called "old rules" and its size does not depend on the amount of insurance premiums paid. Since then, several stages of the pension reform have taken place. The new pension legislation was approved in 2011. It provided for the creation of new firstlevel sub-accounts financed by insurance premiums, which were previously paid to the second level.

In 2014, another law was adopted that introduced changes to the functioning of the second pillar of the national pension system in Poland. According to this law, the second level for all new participants in the labour activity has become voluntary, as well as the third. Active second-tier members may also opt-out of it, then all their funds accumulated on individual accounts will be transferred to the first level of insurance (European Experience of ..., 2017). The third level of insurance is voluntary. It covers professional pension systems, individual retirement accounts and individual pension account security. (Parlinska A., 2011) At the present stage of the pension reform in Poland, changes were made to the size of the retirement age. From 1 October 2017, rules are being revised to reduce the retirement age of men to 65 and women to 60 years. Earlier, it gradually grew up to 67 years for both sexes (Social Security in Poland, 2017).

Table 1

Countries with the highest rates of population decline in 2015-2050

\begin{tabular}{|l|c|c|c|c|}
\hline \multirow{2}{*}{ Countries } & \multicolumn{2}{c|}{$\begin{array}{c}\text { Population, } \\
\text { thousand persons }\end{array}$} & \multicolumn{2}{c|}{ Changing the number } \\
\cline { 2 - 5 } & $\mathbf{2 0 1 5}$ & $\mathbf{2 0 5 0}$ & Persons & \% \\
\hline Bulgaria & 7150 & 5154 & -1996 & -27.9 \\
\hline Romania & 19511 & 15207 & -4304 & -22.1 \\
\hline Ukraine & 44824 & 35117 & -9707 & -21.7 \\
\hline Bosnia and Herzegovina & 3810 & 3069 & -741 & -19.4 \\
\hline Latvia & 1971 & 1593 & -378 & -19.2 \\
\hline Lithuania & 2878 & 2375 & -503 & -17.5 \\
\hline Serbia & 8851 & 7331 & -1520 & -17.2 \\
\hline Croatia & 4240 & 3554 & -686 & -16.2 \\
\hline Hungary & 9855 & 8318 & -1537 & -15.6 \\
\hline Poland & 38612 & 33136 & -5476 & -14.2 \\
\hline Estonia & 1313 & 1129 & -184 & -14.0 \\
\hline
\end{tabular}

Source: authors' calculation on the base World Population Prospects: The 2015 Revision, Key Findings and Advance Tables. - New York: United Nations, Department of Economic and Social Affairs (2015)

The countries of Eastern Europe and Ukraine, in the face of a rather high level of aging in Europe, noticed the problems with a sharp decline in the population. Compared to Western European and Scandinavian countries, they currently have and are predicting a much higher rate of population decline (Table 1). According to scientists, it is precisely in those countries where the population is aging and decreasing, the greatest problems with social protection of retirement age citizens will arise (When Should the State Pension ..., 2010). The highest rates of population decline are projected in Bulgaria, Romania and Ukraine. By 2050, the number of citizens in these countries by calculation may decrease by $27.9 \%, 22.1 \%$, and $21.7 \%$, respectively. This state of affairs in the pension sector prompts governments in these countries to carry out the next stages of pension reform.

In Bulgaria, in recent years, there have been two stages of the pension reform, which envisaged an increase in retirement age, and reduction of privileged persons in various sectors of the economy. In 2015 , the reform of the pension sector was partially frozen. Today, implementation of the next 
stage of the reform of the national pension system is taking place. Among the key issues is the question of changing the retirement age and increasing the length of insurance experience. This issue pays considerable attention to the implementation of the current stage of pension reform in Ukraine. In Bulgaria, it is planned that the retirement age for men and women will be equal and in 2037, should reach 65 years. Regarding the amount of insurance experience, it will gradually increase until it reaches 40 years for men and 37 for women in 2027. According to experts, citizens who have a longer working period before retirement will receive a higher rate, and consequently, a higher pension. Thus, the government plans to achieve two effects: on the one hand, to encourage citizens to work longer, on the other - to stimulate the full legalization of business and tax payments. As a result, both factors will affect the increase in the number of jobs in the Bulgarian economy (The World's Pension Systems ..., 2015).

Table 2

The rating of quality of life and well-being of the elderly people of countries of Eastern Europe and Ukraine (2015)

\begin{tabular}{|c|c|c|c|c|c|c|c|c|c|c|}
\hline \multirow[b]{2}{*}{ Countries } & \multicolumn{2}{|c|}{ General } & \multicolumn{2}{|c|}{$\begin{array}{l}\text { Material } \\
\text { security }\end{array}$} & \multicolumn{2}{|c|}{ Health status } & \multicolumn{2}{|c|}{$\begin{array}{c}\text { Employment } \\
\text { and } \\
\text { education }\end{array}$} & \multicolumn{2}{|c|}{$\begin{array}{l}\text { Favourable } \\
\text { environment }\end{array}$} \\
\hline & 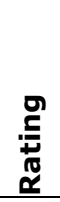 & 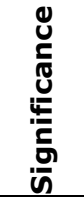 & 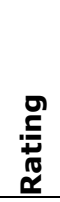 & 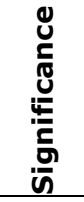 & 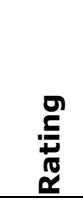 & 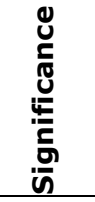 & 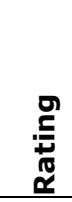 & 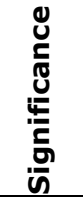 & 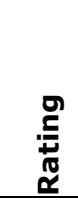 & 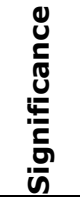 \\
\hline $\begin{array}{l}\text { Czech } \\
\text { Republic }\end{array}$ & 22 & 65.6 & 12 & 81.8 & 47 & 56.1 & 17 & 54.4 & 50 & 65.8 \\
\hline Estonia & 23 & 64.9 & 44 & 70.7 & 55 & 50.0 & 6 & 64.8 & 39 & 68.1 \\
\hline Slovenia & 26 & 60.6 & 25 & 77.7 & 38 & 63.2 & 79 & 23.9 & 7 & 79.2 \\
\hline Poland & 32 & 57.4 & 26 & 77.6 & 48 & 55.3 & 52 & 31.1 & 37 & 69.2 \\
\hline Latvia & 35 & 55.2 & 34 & 74.5 & 66 & 44.1 & 15 & 57.0 & 68 & 60.1 \\
\hline Hungary & 39 & 52.2 & 38 & 73.2 & 57 & 47.4 & 41 & 35.8 & 60 & 63.1 \\
\hline Slovakia & 40 & 52.1 & 21 & 78.7 & 53 & 28.2 & 28 & 45.6 & 80 & 58.5 \\
\hline Romania & 45 & 50.8 & 22 & 78.4 & 64 & 44.9 & 46 & 34.1 & 64 & 62.0 \\
\hline Bulgaria & 49 & 49.7 & 46 & 67.9 & 68 & 40.0 & 27 & 47.5 & 69 & 59.8 \\
\hline Croatia & 61 & 44.0 & 67 & 50.5 & 49 & 55.3 & 56 & 30.0 & 72 & 58.9 \\
\hline Lithuania & 63 & 43.2 & 53 & 63.8 & 65 & 44.2 & 21 & 50.0 & 90 & 52.6 \\
\hline Serbia & 66 & 41.7 & 49 & 65.8 & 62 & 45.3 & 80 & 21 & 67 & 60.2 \\
\hline Montenegro & 68 & 39.7 & 61 & 56.3 & 56 & 49.1 & 82 & 20.6 & 70 & 58.9 \\
\hline Ukraine & 73 & 37.0 & 42 & 70.9 & 85 & 27.3 & 44 & 34.8 & 85 & 54.8 \\
\hline
\end{tabular}

Source: authors' calculation on the base Global AgeWatch Index 2015: Insight Report Summary -

https://www.ageinternational.org.uk/Documents/Global_AgeWatch_Index_2015_HelpAge.pdf.

Romania also has a three-tier pension model. The research results show, that the pension reform is being implemented successfully in this country. Along with the joint pension system, the second and third levels are being developed, which are based on the use of accumulative pension programs. Pension funds of the second and third levels have become the largest national institutional investors and leading stock market participants, as evidenced by the results of the analysis published by the Association of Pension Funds of Romania ARARR. In 2015, seven funds at Level II and ten funds at Level III manage assets with an aggregate value of almost 5 billion EUR (Romanian Pension Fund ..., 2015).

In describing the functioning of national pension systems in Eastern Europe and Ukraine, according to experts from the Razumkov Center, it is important to assess the level of social security and welfare of people of retirement age (Pishchulina O. 2017). One of the main indicators of this level assessment is the Global Quality of Life and Elder Life Index. Since 2013, it is determined by 
the international non-governmental organization "HelpAge International" in association with the UN Population Fund (HelpAge International ... , 2015)

According to the results of such an assessment among East European countries in 2015, the quality of life and well-being of elderly people is highest in the Czech Republic, in the second place Estonia, in the third - in Slovenia (Table 2). It is worth noting that the Czech Republic is among those twenty countries in the world with the highest global index. For Ukraine this indicator is rather low, and in general in the world rating in 2015 it occupied only 73 $3^{\text {rd }}$ place (Pishchulina 0. 2017).

This indicates that the pension system of Ukrainian pensioners today is not sufficiently developed and effective, thus not providing them with a decent standard of living, proper social standards and opportunities for social realization.

\section{Conclusions}

Summarizing the above research, it should be noted that all without exception, the countries of Eastern Europe and Ukraine, are at the stage of reforming their national pension systems. The main factors contributing to the reform of pension systems are demographic processes that take place in society. They are characterized by a decrease in fertility, an increase in the proportion of older people and as a result of the aging population.

For Eastern European countries and Ukraine, the peculiarity is that along with the aging of the population at a rather rapid pace, in comparison with Western European countries, its reduction is projected. Such trends affect the deterioration of the financial position of national pension systems and the ability of the state to meet its obligations to citizens of retirement age. Therefore, the governments of the countries in the given region of Europe are constantly looking for options for solving issues in the pension sector, through holding the next stages of the pension reform. The ultimate goal of pension reform is to increase the social standards of citizens of retirement age to the accepted international standards.

Studies show that the national pension system of Ukraine is in a state of serious crisis. It manifests itself at a low level of pensions, the lack of proper differentiation in the size of retirement benefits, depending on the length of service, the deficit of the Pension Fund budget, and, consequently, the significant attraction of funds from the state budget. Therefore, further reformation of the state pension system is an objective necessity and one of its main tasks on the path to European integration.

\section{Bibliography}

1. Annex II. The Madrid International Plan of Action on Aging 2002. Report of the Second World Assembly on Aging. Madrid, April 8-12, 2002, UN, Retrieved: http://www.un.org/ru/ documents / decl_conv / declarations / pdf. Access: 10.11.2018.

2. Convention of the International Labor Organization "On Minimum Social Security" of June 28, 1952, No. 102. - Retrieved: www.kiev.gov.ua. Access: 20.10.2018.

3. Convention of the Organization for Economic Co-operation and Development of December 14, (1960). Retrieved: http: //www.oecd.org/daf/corporate/principles. Access: 10.11.2018.

4. Establishing a European Pillar of Social Rights. Commission Staff Working Document SWD (2017) 201 final, Brussels: European Commission, 07/26/2017, 77p. - Retrieved: http://eur-lex.europa.eu/legalcontent/EN/TXT/PDF/?uri=CELEX:52017SC0201\&from=EN. Access: 20.10.2018.

5. Global AgeWatch Index 2015: Insight report summary (2015). Retrieved: https://cdn.uclouvain.be/public/Exports \%20reddot/aisblgenerations/documents/DocPart_Etud_GlobalAgeWatchIndex_2015.pdf. Access: 15.01.2019.

6. HelpAge International: The Quality Of Life Index For The Elderly In The World In 2015(2015). Analytical portal "Humanitarian Technologies", Retrieved: http://gtmarket.ru/news/2015/09/28/7245.Access: 15.01.2019.

7. Parlinska A., Rozwoj rynku pracowniczych programów emerytalnych, (Development Of Occupational Pension Schemes' Market), (2011), No 167, Prace Naukowe Uniwersytetu Ekonomicznego we Wrocławiu, pp. 265277. 
8. Pensiyna Reforma: Pershi Doslidzhennya Naslidkiv (Pension Reform: First Impact Studies) (2017). Retrieved: http://www.atomprofspilka.info/public/lrr556677. Access: 15.01.2019.

9. Pensiyni Systemy Svitu: Vid Kryz Do Reform (The World's Pension Systems: From Crises to Reforms) (2015). Retrieved: http://cost.ua/news/165-pension-crisis. Access: 15.01.2019.

10. Pishchulina O. (2017). Financial, Social And Legal Aspects Of Pension Reform In Ukraine. World Experience And Ukrainian Realities .// O. Pischulina, O. Koval, T. Burlay. - K .: Razumkov Center: "Zapovit" Publishing House - 2017. 453c.

11.Population Structure and Ageing, Eurostat (2018). Retrieved: https://ec.europa.eu/eurostat/statisticsexplained/index.php/Population_structure_and_ageing Access:15.01.2019.

12. Romanian Pension Fund Investment In Bucharest Stock Exchange Tops €800m (2015). Retrieved: https://www.ipe.com/countries/cee/romanian-pension-fund-investment-in-bucharest-stock-exchange-tops$800 \mathrm{~m} / 10007882$ article. Access: 15.01.2019.

13. Social Security in Poland, (2017). ZUS, Retrieved: http://www.zus.pl/documents/10182/167615/Social+Security+in+Poland/71ffe1b1-c142-48fa-a67b0c7e1cec6eb6. Access: 15.01.2019.

14. When Should the State Pension Age Increase To 66? A Call for Evidence (2010). Retrieved: https://assets.publishing.service.gov.uk/government/uploads/system/uploads/attachment_data/file/184776 /spa-inc-to-66-call-for-evidence.pdf. Access: 15.01.2019.

15. World Bank Statistics. Retrieved: http://www5.worldbank.org/eca/russian/data/. Access: 20.10.2018.

16. World Population Prospects: The 2015 Revision, Key Findings and Advance Tables. New York: United Nations, Department of Economic and Social Affairs, (2015), Retrieved: https://esa.un.org/unpd/wpp/publications/files/key_findings_wpp_2015.pdf. Access: 20.03.2018.

17. Yevropeys' kyy Dosvid Pensiynykh Reform (European Experience of Pension Reform) (2017). Retrieved: http://www.uezd.com.ua/evropejskyj-dosvid-pensijnyh-reform/. Access: 15.01.2019. 